\title{
World Experience in Nuclear Steam Reheat
}

\author{
Eugene Saltanov and Igor Pioro \\ University of Ontario Institute of Technology (UOIT) \\ Faculty of Energy Systems and Nuclear Science \\ Canada
}

\section{Introduction}

Concepts of nuclear reactors cooled with water at supercritical pressures were studied as early as the 1950s and 1960s in the USA and Russia. After a 30-year break, the idea of developing nuclear reactors cooled with SuperCritical Water (SCW) became attractive again as the ultimate development path for water cooling. This statement is based on the known history of the thermal power industry, which made a "revolutionary" step forward from the level of subcritical pressures $(15-16 \mathrm{MPa})$ to the level of supercritical pressures $(23.5-35$ $\mathrm{MPa}$ ) more than fifty years ago with the same major objective as that of SuperCritcal Watercooled Reactors (SCWRs) - to increase thermal efficiency of power plants by $10-15 \%$. The main objectives of using SCW in nuclear reactors are: 1) to increase the thermal efficiency of modern Nuclear Power Plants (NPPs) from $30-35 \%$ to about $45-50 \%$, and 2) to decrease capital and operational costs and hence, decrease electrical-energy costs.

To achieve higher thermal efficiency a nuclear steam reheat has to be introduced inside a reactor. Currently, all supercritical turbines at thermal power plants have a steam-reheat option. In the $60^{\prime}$ s and $70^{\prime}$ s, Russia, USA and some other countries have developed and implemented the nuclear steam reheat at a subcritical pressure in experimental boiling reactors. Therefore, it is important to summarize the experience of implementing nuclear steam reheat at several experimental Boiling Water Reactors (BWRs) worldwide and utilize it in the context of development of SCWRs with the steam-reheat option.

\section{USA experience in nuclear steam reheat}

An active program for the development and demonstration of BWRs with nuclear steam reheat was implemented and directed by the United States Atomic Energy Commission (USAEC). Two general types of the reactors were demonstrated:

1. Reactors in which steam was generated and reheated in the same core (integral reheating design); and

2. Reactors, which only used reheated steam that was supplied from another source (separate reheating design);

Under the USAEC program, the following reactors were constructed: BOiling Reactor Experiment V (BORAX-V, started operation in December of 1962), BOiling NUclear Superheater (BONUS, started operation in December of 1964), and Pathfinder (started operation in July of 1966). Main parameters of these reactors are listed in Tables 1 and 2 (Novick et al. 1965). 
At the design stage of these reactors a certain number of problems arising with the implementation of steam reheat were encountered and addressed. Among them were:

1. Fuel-element sheath performance and corrosion resistance at high temperatures;

2. Corrosion, erosion, and deposits on fuel-element surfaces due to ineffective steam separation prior to the reheating-zone inlet;

3. Maintenance of the desired power split in the evaporating and reheating zones during extended reactor operation;

4. Fission products carry-over in direct-cycle systems; And

5. Reactivity changes as a result of inadvertent flooding of the reheating zone.

In search of the solutions to these problems USAEC also instituted a number of programs to determine long-term integrity and behavior of the fuel-element sheath. Since May of 1959, the Superheat Advance Demonstration Experiment (SADE) and the subsequent Expanded SADE (ESADE) loops had been utilized to irradiate a total of 21 fuel elements in the Vallecitos BWR. Saturated steam at about 6.9 MPa from the Vallecitos BWR was supplied to the fuel-element section where it was superheated to temperatures of $418-480^{\circ} \mathrm{C}$. The results of those irradiation tests combined with out-of-core corrosion tests led to the following conclusions (Novick et al. 1965):

1. Commercial 18-8 stainless steel (18-8 SS) was not satisfactory for fuel-sheath material in the SuperHeated Steam (SHS) environment it was subjected to in the SADE and ESADE experiments;

2. Materials with higher nickel-alloy content, such as Inconels and Incoloys, appeared to perform satisfactorily as a sheath material in the SHS environment; And

3. Strain cycling coupled with environmental chemistry were significant in the failure rate of sheath materials for reactors with the steam reheat.

Additional information on design of these reactors constructed under the USAEC program can be found in USAEC reports 1959, 1961, and 1962 and in Ross (1961).

\begin{tabular}{|c|c|c|c|c|c|c|}
\hline \multirow{3}{*}{ Parameters } & \multirow{2}{*}{\multicolumn{2}{|c|}{$\frac{\text { BORAX-V }}{\text { Zone }}$}} & \multirow{2}{*}{\multicolumn{2}{|c|}{$\frac{\text { BONUS }}{\text { Zone }}$}} & \multirow{2}{*}{\multicolumn{2}{|c|}{$\begin{array}{c}\text { Pathfinder } \\
\text { Zone }\end{array}$}} \\
\hline & & & & & & \\
\hline & Boiling & SHS & Boiling & SHS & Boiling & SHS \\
\hline $\begin{array}{c}\text { Structural } \\
\text { material (core) }\end{array}$ & $\mathrm{A} 1(\mathrm{X} 8001)$ & SS & $\mathrm{Zr}-2$ & SS-248 & $\mathrm{Zr}-2$ & SS \\
\hline Fuel type & Rod & Plate & Rod & Rod & Rod & Annular \\
\hline Fuel material & $\mathrm{UO}_{2}$ & $\begin{array}{l}\mathrm{UO}_{2}-\mathrm{SS} \\
\text { cermet }\end{array}$ & $\mathrm{UO}_{2}$ & $\mathrm{UO}_{2}$ & $\mathrm{UO}_{2}$ & $\begin{array}{l}\mathrm{UO}_{2}-\mathrm{SS} \\
\text { cermet }\end{array}$ \\
\hline $\begin{array}{c}\text { Fuel enrichment, } \\
\%\end{array}$ & 4.95 & 93 & 2.4 & 3.25 & 2.2 & 93 \\
\hline Sheath material & SS-304 & SS-304L & $\mathrm{Zr}-2$ & Inconel & $\mathrm{Zr}-2$ & SS-316L \\
\hline $\begin{array}{l}\text { Control rod } \\
\text { shape }\end{array}$ & $\begin{array}{l}\text { Cruciform } \\
\text { and "T" }\end{array}$ & $\begin{array}{l}\text { Cruciform } \\
\text { and " } \mathrm{T} "\end{array}$ & Cruciform & Slab & Cruciform & Round rod \\
\hline $\begin{array}{c}\text { Control rod } \\
\text { material }\end{array}$ & Boral & Boral & $\begin{array}{c}1.0 \%{ }_{\mathrm{wt}^{10}} \mathrm{~B} \\
\text { in SS }\end{array}$ & $\begin{array}{l}1.0 \% \mathrm{wt}^{10} \mathrm{~B} \\
\text { in SS }\end{array}$ & $\begin{array}{c}2 \%{ }_{w_{t}^{10}}^{10} \mathrm{~B} \text { in } \\
\text { SS }\end{array}$ & $\begin{array}{c}2 \% w_{w^{10}}{ }^{10} \text { in } \\
\text { SS }\end{array}$ \\
\hline $\begin{array}{c}\text { Average power } \\
\text { density, } \\
\mathrm{MW}_{\mathrm{th}} / \mathrm{m}^{3}\end{array}$ & 42.5 & 40.5 & 33.6 & 11.5 & 45.2 & 46.5 \\
\hline
\end{tabular}

Table 1. Main general parameters of BWR NPPs with integral reheat design (Novick et al. 1965). 


\begin{tabular}{|l|c|c|c|}
\hline \multicolumn{1}{|c|}{ Parameters } & BORAX-V & BONUS & Pathfinder \\
\hline Electric power, $\mathrm{MW}_{\mathrm{el}}$ (gross) & 3.5 & 17.5 & 66 \\
\hline Electric power, $\mathrm{MW}_{\mathrm{el}}$ (net) & 3.5 & 16.5 & 62.5 \\
\hline Thermal power, $\mathrm{MW}_{\text {th }}$ & 20 & 50 & 200 \\
\hline Reheat loop to evaporating loop power ratio & 0.21 & 0.35 & 0.22 \\
\hline Gross cycle thermal efficiency, \% & - & 35 & 33 \\
\hline Net cycle thermal efficiency, \% & - & 33 & 31 \\
\hline NPP steam cycle & Direct & Direct & Direct \\
\hline \multirow{2}{*}{ Reheating-zone location } & $\begin{array}{c}\text { Central or } \\
\text { Peripheral }\end{array}$ & Peripheral & \multirow{2}{*}{ Central } \\
\hline Nominal operating pressure, $\mathrm{MPa}$ & 4.1 & 6.7 & 4.1 \\
\hline
\end{tabular}

Table 2. Main thermal parameters of BWR NPPs with integral reheat design (Novick et al. 1965).

The major conclusion, which is based on the USA experience with the nuclear steam reheat, is that the nuclear steam reheat is possible, and higher thermal efficiencies can be achieved, but this feature requires more complicated reactor-core design and better materials.

\section{Russian experience in nuclear steam reheat}

This section presents a unique compilation of materials that overviews all major aspects of operating experience of the first in the world industrial NPP with implemented nuclear steam reheat.

\subsection{General information}

Reactors with the nuclear steam reheat were also developed in the former Soviet Union. Beloyarsk Nuclear Power Plant (BNPP) was the first NPP in the world where the nuclear steam reheat was implemented. Two reactors $\left(100 \mathrm{MW}_{\mathrm{e}}\right.$ and $\left.200 \mathrm{MW}_{\mathrm{e}}\right)$ were installed with identical steam parameters at the turbine inlet $\left(P_{\text {in }}=8.8 \mathrm{MPa}\right.$ and $\left.T_{\text {in }}=500-510^{\circ} \mathrm{C}\right)$. The first reactor (Unit 1) was put into operation on April 26, 1964, and the second reactor (Unit 2) on December 29, 1967. Both reactors have similar dimensions and design. However, the flow diagram and the core arrangement were significantly simplified in Unit 2, compared to that of Unit 1. Schematics and simplified layouts of the BNPP Units 1 and 2 are shown in Figures 1 and 2.

Operation of BNPP has proved the feasibility of steam-reheat implementation on an industrial scale. Major results of the BNPP operation are listed below (Petrosyants 1969):

1. Reactor start-up from the cold state was achieved without external heat sources. The reactor heat-up was carried out at $10 \%$ power until the water temperature in the separators reached $285-300^{\circ} \mathrm{C}$ at $8.8 \mathrm{MPa}$. Levels in the separators were formed during heat-up. Transition from water to steam cooling in the SHS channels did not cause significant reactivity changes.

2. The radial neutron flux flattening achieved was one of the best among operating reactors. The radial neutron flux irregularity coefficient, $K_{i r}$, for both units was $1.28-$ 1.30, while the design values were: $K_{i r}=1.46$ for Unit 1 and $K_{i r}=1.24$ for Unit 2.

3. Radioactivity in the turbine and technological equipment of the plant is an important indicator for NPP. Radiation rates at the high-pressure cylinders were not higher than $10 \mu \mathrm{R} / \mathrm{s}$ and not higher than $8 \mu \mathrm{R} / \mathrm{s}$ at the low-pressure cylinders. Such low dose rates 
were attained by implementation of fuel elements that eliminated the possibility of fission-fragment activity transported via the coolant loop. BNPP operation experience showed that radiation levels near Unit 1 equipment were significantly lower than that of other operating reactors, and releases of radioactive products into the atmosphere were 5 - 10 times lower than allowed by codes.

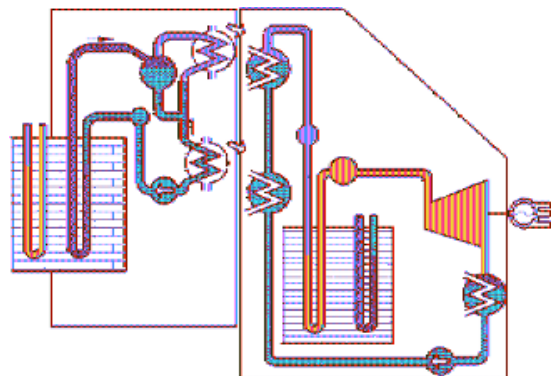

(a)

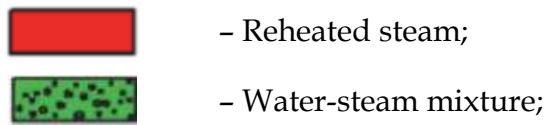

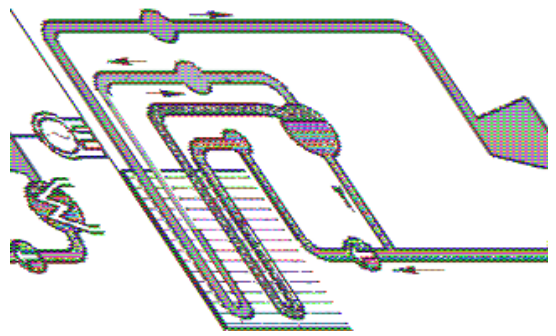

(b)

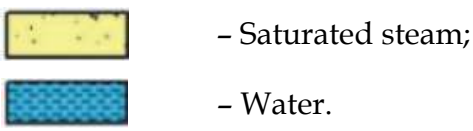

Fig. 1. BNPP Unit 1 (a) and Unit 2 (b) general schematics of thermodynamic cycle (Yurmanov et al. 2009a):

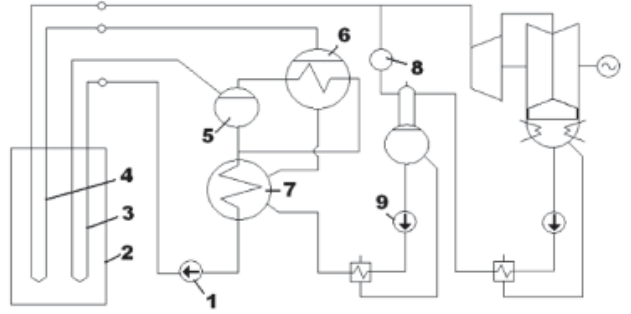

(a)

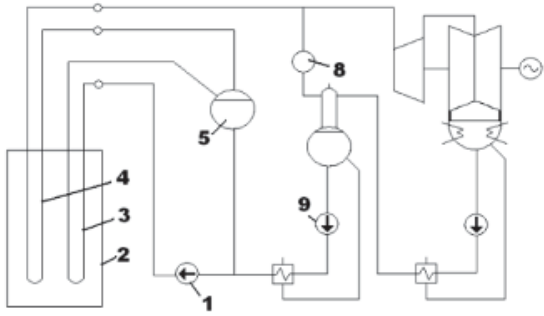

(b)

Fig. 2. Simplified layout of BNPP Unit 1 (a) and Unit 2 (b) (Petrosyants 1969): 1 - circulation pump; 2 - reactor; 3 - Boiling Water (BW) channels; 4 - SHS channels; 5 - steam separator; 6 - Steam Generator (SG); 7 - economizer; 8 - bubbler; and 9 - Feed Water Pump (FWP).

\subsection{Cycle development}

Reliability, simple design, and efficiency are the main criteria when choosing the flow diagram for both the fossil and nuclear power plants. Special requirements for impermeability and water regime are specified for NPPs. Additionally, the reasonable development of temperature regimes for fuel channels allows safe power increase for the a reactor size.

Several layouts of thermodynamic cycles for a NPP with a uranium-graphite reactor were considered for the BNPP (see Figure 3). In the considered layouts the coolant was either boiling water or superheated steam. Feasibility of the NPP designs was also taken into account (Dollezhal et al. 1958). 


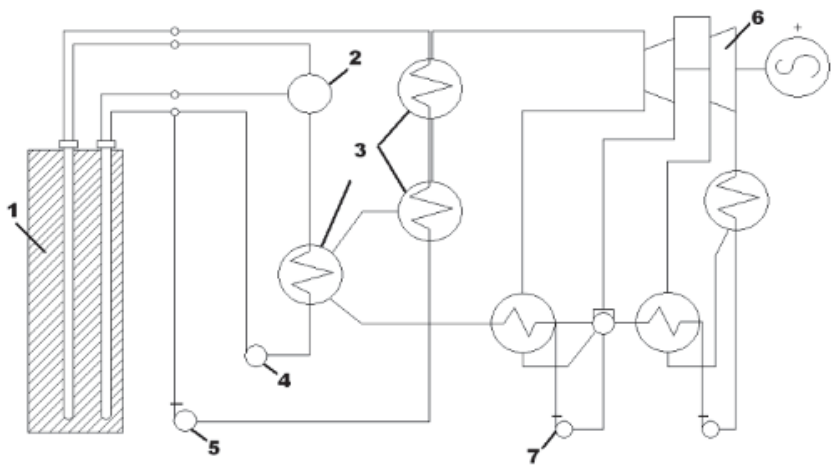

(a)

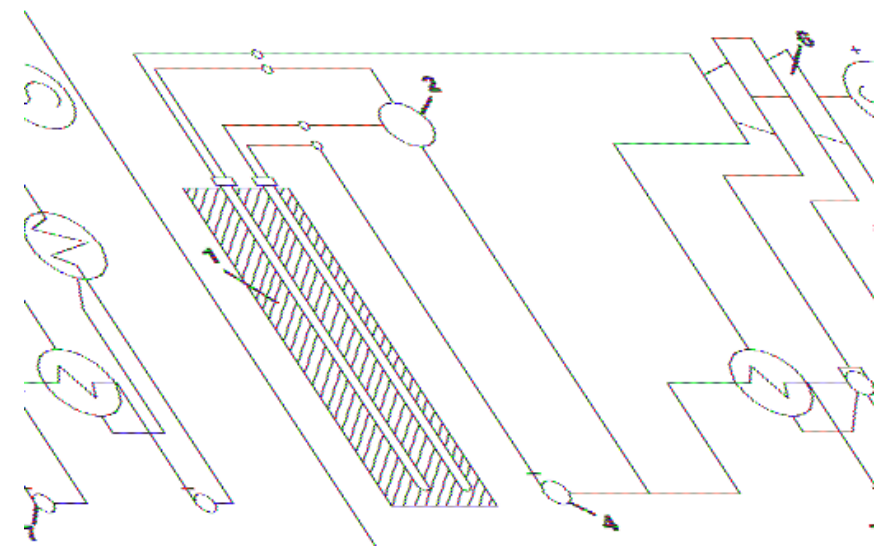

(b)

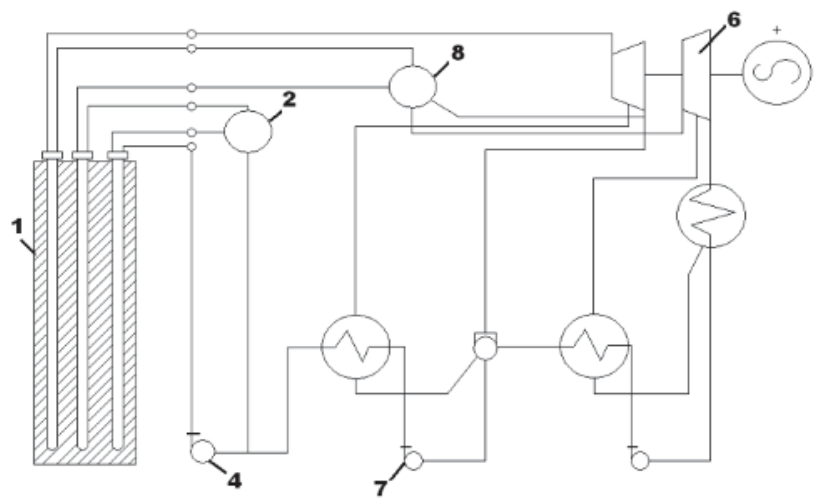

(c) 


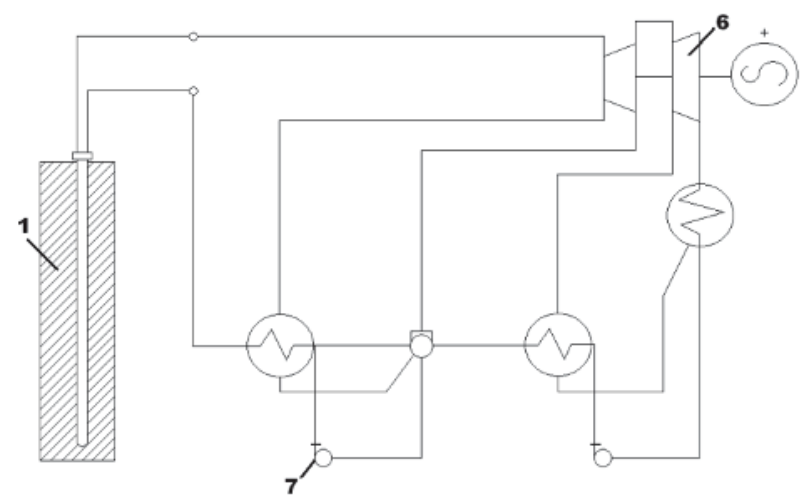

(d)

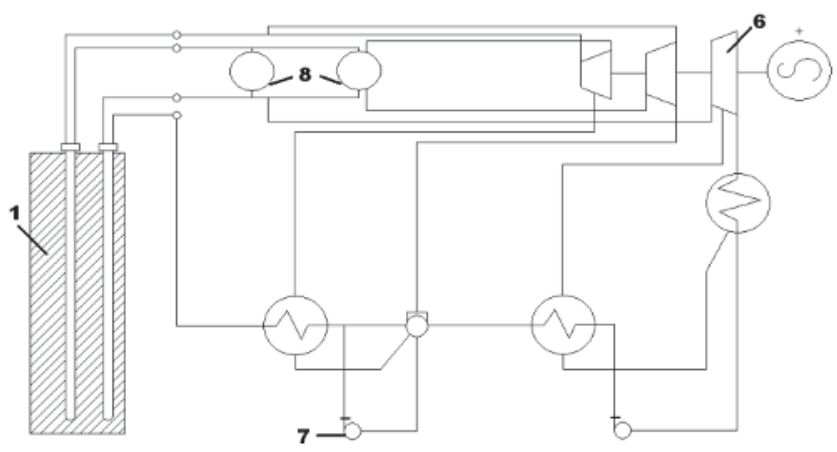

(e)

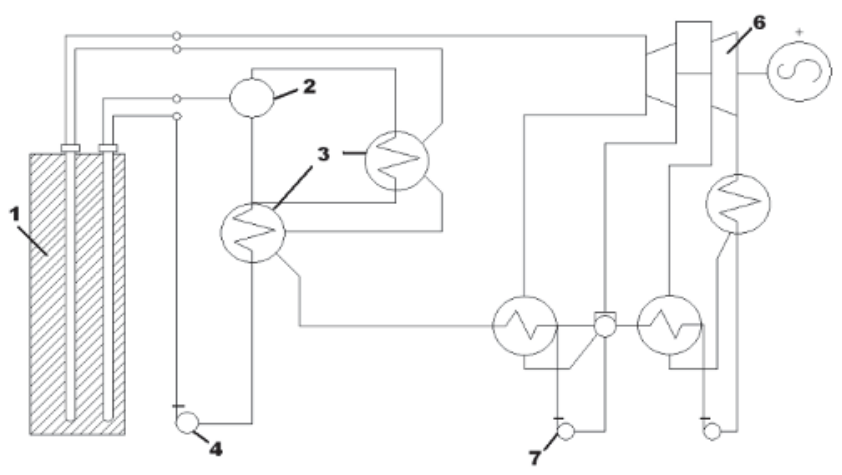

(f)

Fig. 3. Possible layouts of NPPs with steam reheat (Dollezhal et al. 1958): 1 - reactor; 2 steam separator; 3 - SG; 4 - Main Circulation Pump (MCP); 5 - circulation pump; 6 - turbine with electrical generator; 7 - FWP; and 8 - intermediate-steam reheater. 
Layout (a). A steam separator, steam generator (consisting of preheating, boiling and steamsuperheating sections), and two circulation pumps are included in the primary coolant loop. Water and very high-pressure steam are the primary coolants. High- and intermediatepressure steam is generated in the secondary loop and directed to the turbine.

Layout (b). Direct-cycle layout. Steam from a reactor flows directly to a turbine. The turbine does not require an intermediate-steam reheat.

Layout (c). Steam from a reactor flows directly to a turbine. The turbine requires the intermediate-steam reheat. The reactor has three types of operating fuel channels: 1) water preheating, 2) evaporating-boiling, and 3) steam-superheating.

Layout (d). Direct-cycle layout. The evaporation and reheat are achieved inside a reactor. The turbine does not require the intermediate-steam reheat.

Layout (e). Direct-cycle layout. One or two intermediate-steam reheats are required.

Layout (f). Water circulates in the closed loop consisting of a reactor, steam separator, preheater, and circulation pump. Partial evaporation is achieved in the first group of channels. Steam exiting the steam separator is directed to the boiling section of the steam generator and condenses there. Condensate from the boiler is mixed with water from the separator. The cooled water is fed to a preheater and then directed to circulation pumps. The generated steam on the secondary side is superheated in the second group of channels and then directed to the turbine.

Layouts (b-e) were not recommended due to unpredictable water-chemistry regimes at various locations throughout the thermodynamic cycle. Layout (a) with the secondarysteam reheat required high pressures and temperatures in the primary loop. Circulation pumps with different parameters (power and pressure) were used to feed common header upstream of the channels of the primary group. In this respect, Layout (a) was considerably more complex and expensive than Layout (f). Activation of SHS, which could occur in Layout (f), was not considered to be posing any significant complications to the turbine operation, and hence remained a viable option (Dollezhal et al. 1958).

From the considerations above, Layout (f) was chosen to be developed at the BNPP Unit 1. Surface-corrosion products in the secondary loop and salts in condenser coolant were trapped in the steam generator and removed from it during purging. Additionally, modern separators provided steam of high quality, which resulted in very low salt deposits in the turbine.

\subsection{Beloyarsk NPP reactor design}

The reactor was placed in a cylindrical concrete cavity, where a 3-m thick wall served as a part of the biological shield. A cooled ferro-concrete base of the reactor with six base jacks was implemented on the bottom of the cavity. The bottom bedplate attached to the bottom supporting ring was held by jacks. Cooling coils were placed on the bottom of the bedplate to provide its cooling.

The cylindrical graphite stack ( $3 \mathrm{~m}$ in diameter and $4.5 \mathrm{~m}$ in height) of the reactor was installed on the bottom bedplate. The stack was made of columns, assembled of hexagonal blocks (0.12-m width across corners) in the center and of sectors in the periphery. The central part of the stack was penetrated by vertical operating channels (long graphite cylinders containing inner thin steel tubes with fuel elements). The reactor core (7.2-m diameter and $6-\mathrm{m}$ height) was surrounded with a $0.8-\mathrm{m}$ thick graphite reflector. An additional $1-\mathrm{m}$ thick graphite layer and an approximately $0.5-\mathrm{m}$ cast-iron layer over the upper reflector formed the principal part of the biological shield. A 0.6-m thick graphite layer serving as the lower neutron shield was located below the lower reflector. 
The graphite stack (9.6-m overall diameter and 9.0-m height) was enclosed in a gas-tight cylindrical carbon-steel shell filled with nitrogen to prevent graphite deterioration. The outer graphite blocks were penetrated by steel uprights with horizontal lateral braces in several places along their height. The entire stack rested on the bottom bedplate. The graphite stack was covered on the top with a plate carrying standpipes with openings for the insertion of operating channels. The piping for feeding the coolant to the fuel bundles and for removing the coolant water from control rods was located between the standpipes. The piping of the operating channels and protective coating failure-detection system was also located between the standpipes. The plate rested on supports installed on the tank of the side water shield. The plate was connected with the graphite stack shell by means of a compensator, which allowed both for vertical elongations of the shell and horizontal elongations of the plate, which occurred during heating (Emelyanov et al. 1982).

As shown in Figure 4, the reactor had 1134 operating channels and contained 998 fuel channels, 6 automatic control rods, 78 channels for reactivity compensating rods, 16 shutdown rods, and 36 channels for ionization chambers and counters. The fuel channels were represented with $730 \mathrm{BW}$ channels, also referred to as evaporating channels, and $268 \mathrm{SHS}$ channels, also referred to as steam-reheat channels.

The main parameters of the BNPP reactors are listed in Table 3.

\subsection{Physical parameters of Beloyarsk NPP reactors}

Flattening of a power distribution was achieved at the BNPP with physical profiling: appropriate distribution of control rods and fuel channels of different uranium enrichment (for fresh load) and profiling of burn-up fuel along the reactor radius. The reactor load consisted of SHS channels of $2 \%$ and 3\% uranium enrichments (SHS-2 and SHS-3, respectively) and BW channels. The BW channels were located in rings in alternate locations with SHS-2. SHS-3 were located along the circumference and had lower pressure losses in the steam circuit (Dollezhal et al. 1964).

Neutronics calculations were made to choose optimal distribution of channels to achieve required power shape. Most of the calculations for the core-reactor physics were performed in the 2-group approximation. In accordance with the fuel-channels distribution the core was represented by four cylindrical regions with the radii: $R_{1}=175$ $\mathrm{cm}$ (234 fuel channels), $R_{2}=268 \mathrm{~cm}$ (324 fuel channels), $R_{3}=316 \mathrm{~cm}$ (220 fuel channels), and $R_{4}=358 \mathrm{~cm}$ (220 fuel channels). The previous calculations and operating experience of large uranium-graphite reactors with relatively small neutron leakage showed that a simplified schematic could be used when neutron distribution in the reactor is determined by the multiplication characteristics of the reactor regions. The multiplications constants obtained for the 4 regions $\left(k_{i n f, 1}=1.013, k_{i n f, 2}=1.021, k_{i n f, 3}=1.043\right.$, and $\left.k_{i n f, 4}=1.045\right)$ allowed flattening of the neutron distribution along the reactor radius with $K_{i r}=1.20-1.25$. The increase in the multiplication constants values to the periphery of the reactor was attained by placing fuel channels with 3\% uranium enrichment. Refuelling schemes and, therefore, fuel burn-up at different regions were chosen such as to allow designed power flattening in the end of the campaign, with corresponding values of $k_{\text {inf }, i}$. Control rods insertion in the core maintained $k_{i n f, i}$ values in the necessary limits during normal operation (Vikulov et al. 1971). 


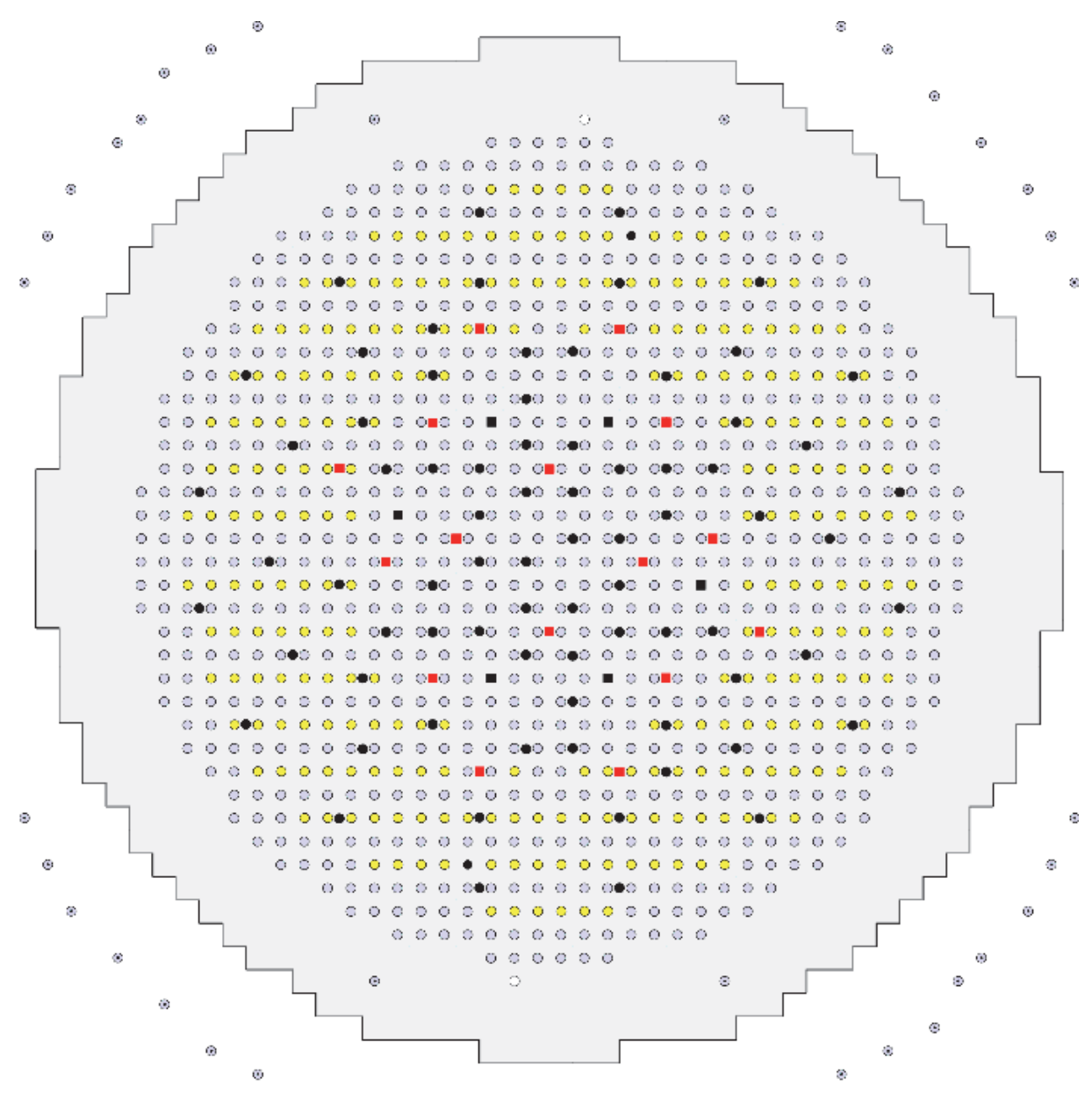

Boiling Water Channels-730

Superheated Steam Channels-268

Channels for Compensating Rods-78

Shut-Down Rods-16

Regulating Rods-6

Counting Chamber Channels-2

- Channels for Start-up Chambers $-4+30$-Channels for lonization Chambers

Fig. 4. BNPP Unit 1 channels layout (Pioro et al. 2010, this figure is based on the paper by Dollezhal et al. 1958). 


\begin{tabular}{|c|c|c|}
\hline Parameters & $\begin{array}{c}\text { BNPP Unit } 1 \\
\text { (730 BWs \& } 268 \text { SHSs) }\end{array}$ & $\begin{array}{c}\text { BNPP Unit } 2 \\
\text { (732 BWs \& } 266 \text { SHSs) }\end{array}$ \\
\hline Electrical power, $\mathrm{MW}_{\mathrm{el}}$ & 100 & 200 \\
\hline Number of K-100-90-type turbines & 1 & 2 \\
\hline Inlet-steam pressure, $\mathrm{MPa}$ & 8.5 & 7.3 \\
\hline Inlet-steam temperature, ${ }^{\circ} \mathrm{C}$ & 500 & 501 \\
\hline Gross thermal efficiency, \% & 36.5 & 36.6 \\
\hline $\begin{array}{l}\text { Total metal content (top \& bottom plates, } \\
\text { vessel, biological shielding tank, etc.), t }\end{array}$ & 1800 & 1800 \\
\hline Weight of separator drums, $\mathrm{t}$ & 94 & 156 \\
\hline Weight of circulation loop, $\mathrm{t}$ & 110 & 110 \\
\hline Weight of graphite stacking, $\mathrm{t}$ & 810 & 810 \\
\hline Uranium load, $\mathrm{t}$ & 67 & 50 \\
\hline Specific load, $\mathrm{MW}_{\text {th }} / \mathrm{t}$ & 4.3 & 11.2 \\
\hline Uranium enrichment, $\%$ & 1.8 & 3.0 \\
\hline $\begin{array}{l}\text { Specific electrical-energy production, } \\
\mathrm{MW}_{\mathrm{el}} \cdot \text { days } / \mathrm{t}\end{array}$ & 4000 & 10000 \\
\hline Square lattice pitch, $\mathrm{mm}$ & 200 & 200 \\
\hline $\begin{array}{l}\text { Core dimensions, } \mathrm{m}: \text { Diameter } \\
\text { Height }\end{array}$ & $\begin{array}{c}7.2 \\
6\end{array}$ & $\begin{array}{c}7.2 \\
6\end{array}$ \\
\hline
\end{tabular}

Table 3. Main parameters of BNPP reactors (Aleshchenkov et al. 1964; Dollezhal et al. 1969, 1971).

One of the requirements to be met when implementing nuclear steam reheat is to maintain a constant specified power split $(\pi)$ between SHS and BW channels during the operating period. The SHS channel temperature up to $520^{\circ} \mathrm{C}$ at the BNPP was obtained by setting $\pi=$ 0.41 at the optimum parameters of the thermodynamic cycle. The number of SHS channels was chosen to provide a $\pi$-value of 0.41 at the partial refuelling scheme where the $K_{i r} \approx 1.25$. The steady-state regime was characterized with small fluctuations of approximately $1 \%$ in the $\pi$-value between the refuellings. Circular arrangement of SHS channels (Unit 1) had an advantage of small $\pi$-sensitivity to the changes in radial neutron flux distributions, while for central arrangement of SHS channels (Unit 2) $\pi$ values were more sensitive (see Table 4 ).

\begin{tabular}{|c|c|c|c|c|}
\hline$\pi$ & 0.408 & 0.429 & 0.452 & 0.494 \\
\hline$K_{\text {eff }}$ & 1.20 & 1.36 & 1.53 & 1.78 \\
\hline
\end{tabular}

Table 4. Steam-superheating-zone power to boiling-zone power ratio $(\pi)$ dependence on neutron flux $K_{\text {eff }}$ for BNPP Unit 2 (Vikulov et al. 1971).

However, preference was given to the central arrangement of SHS channels, because this allowed attaining a higher $\pi$-value (around 12\% higher) with the same number of SHS channels. Additionally, central arrangement of SHS channels provided better multiplication characteristics than BW channels. SHS channels were placed in the central region to increase average fuel burn-up by $10 \%$. It should be noted, that during the initial operation period the burn-up rates were different for BW and SHS channels of fresh load, which led to an unbalance of power between superheating and boiling zones. Figure 5 shows the calculated 
dependence of $\pi$-values and power variations for different types of fuel channels on the power generated by the reactor (Vikulov et al. 1971).

Calculations were performed assuming $K_{i r} \approx 1.25$. A fast decrease in the superheating-zone power relative to that of the boiling zone in the initial period was accounted for by a lower power change in SHS channels due to slightly higher fuel conversion in the low enriched SHS2. Practically achieved values of $K_{i r}$ were approximately 1.4 for Unit 1 and 1.3 for Unit 2.

One of the features of the uranium-graphite reactors cooled with water is the possibility of reactivity change with water-content change in the reactor. Substitution of boiling water with steam in the operating channels leads to the rapid change of coolant average density. Failure of a fuel-element sheath is another possibility of water-content change that was considered while designing the BNPP reactors. The chosen core lattice with respect to reactivity change turned out to be weakly dependent on water-content changes. It was explained by the compensation of effects of increased resonance neutrons captured by increased water content and an increase at the same time of non-productive neutrons absorption (Dollezhal et al. 1964). Normalized thermal-neutrons distribution along the operating channel cell was studied experimentally for the reactor lattice as shown in Figure 6

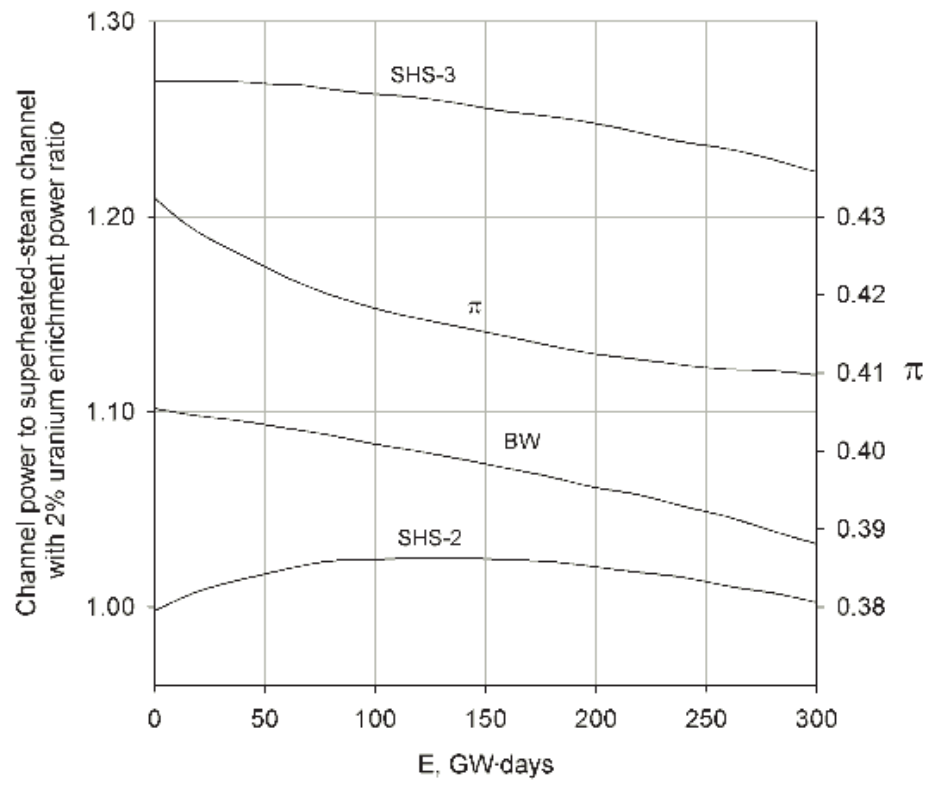

Fig. 5. Channel power ratios and power split between SHS and BW channels $(\pi)$ dependences on burnup produced by BNPP Unit 2 during the first operating period (Vikulov et al. 1971): SHS-3 - superheated steam channel with 3\% uranium enrichment and SHS-2 - superheated steam channel with $2 \%$ uranium enrichment. 
The gradients in the normalized thermal-neutrons distributions along the reactor radius and height for both units indicated a significant disturbance in the normalized thermal-neutron flux near the outer edge of the reactor likely where the steam-reheat channels end affecting the power distribution. The results indicate a more stable distribution for the BNPP Unit 2. Distribution deformation near the end of operating period was explained by non-uniform fuel burn-up. The results proved a possibility of elementary diffusion-theory application for determining neutron distributions and showed the impact of the arrangement of the superheated-steam channels on power distribution.
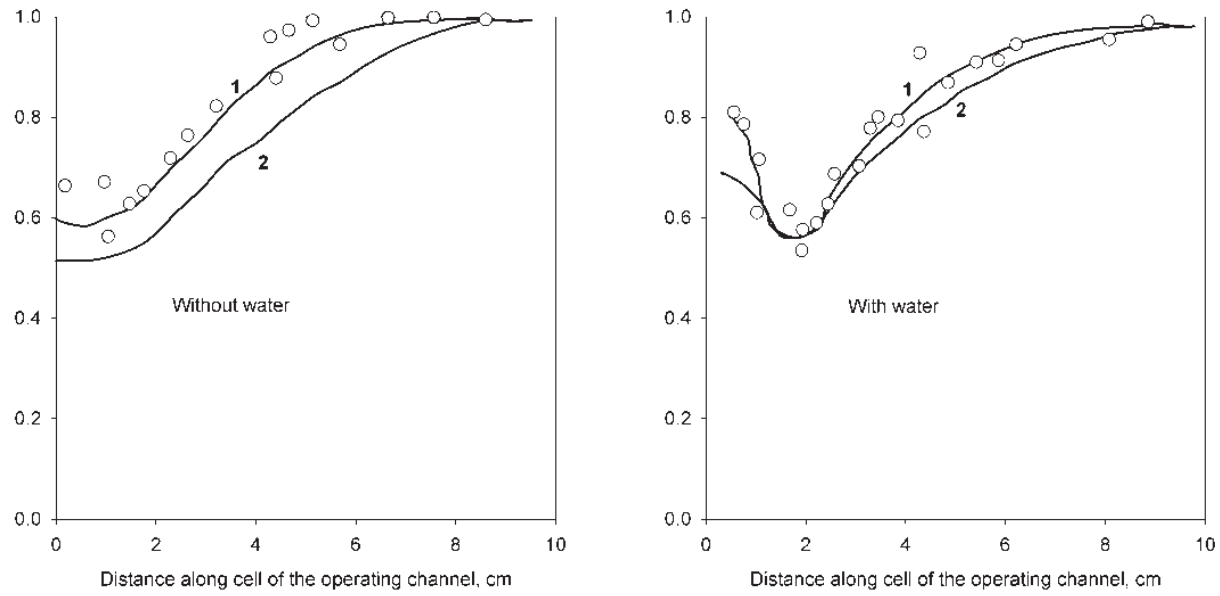

Fig. 6. Normalized thermal-neutrons-density distribution along cell of the operating channel (Dollezhal et al. 1958): 1 - experimental curve and 2 - design curve.

\subsection{Boiling-water channels}

Fault-free operation of BW channels was achieved with reliable crisis-free cooling of bundles and avoiding interchannel and subchannel pulsations of the coolant-flow rate. The appropriate experiments were performed during design of the BNPP. As the result of increased power, the inner diameter of the fuel element was increased from $8.2 \mathrm{~mm}$ for Unit 1 to $10.8 \mathrm{~mm}$ for Unit 2. Note that an annular-fuel design is used and increasing the inner diameter results in thinner fuel and lower-centerline temperatures. Coolant is on the inside of the annular fuel and graphite is on the outside of the fuel.

Experiments were performed at different pressures and equal heat flux, steam content and coolant mass fluxes and showed that wall temperature increases at the boiling crisis was higher when coolant pressure was lowered. At the same time, with the lowered coolant pressure the critical steam content increased. The experiments on hydrodynamic stability showed that mass-flux pulsations within the region of high steam content did not introduce danger for the BNPP reactors, because nominal pressure in the evaporating loop was 8.8 $\mathrm{MPa}$ and steam content at the channels outlet was not higher than $35 \%$. Wall-temperature oscillations were in the phase with the subchannel flow-rate pulsations. With the increased pressure both the amplitude of temperature oscillations and coolant flow rate decreased. 
The same effect occurred at the decreased heat flux and increased flow rate per channel. Wall-temperature oscillations were within the range of $65^{\circ} \mathrm{C}$ at $1000 \mathrm{~kg} / \mathrm{h}$ flow rate and $30^{\circ} \mathrm{C}$ at $1500 \mathrm{~kg} / \mathrm{h}$ flow rate at constant pressure of $4.9 \mathrm{MPa}$ and $0.2 \mathrm{MW}$ power (Dollezhal et al. 1964).

Fuel elements of larger inner diameter used at Unit 2 compared to that of Unit 1 allowed to lower heat flux and hydraulic resistance. With the equal outer diameter $(20 \mathrm{~mm})$, fuel elements inner diameter of the BWs at Unit 1 were $9.4 \times 0.6 \mathrm{~mm}$ while that of Unit $2-12 \times$ $0.6 \mathrm{~mm}$. Diameter of the central tube for feeding the coolant was also increased. There were no other differences in the BWs construction used at BNPP Units 1 and 2. Uraniummolybdenum alloy with magnesium filler was used as fuel in the BWs.

\subsection{Superheated-steam channels}

At the BNPP, SHS channels were operated at higher temperatures compared to those in the BW channels and, therefore, limited the choice of fuel composite and materials. The development of fuel elements for SHS channels underwent several stages. Preliminary tests on the manufacturing technology and performance of fuel elements of various designs were made. As the result, a tubular fuel element with a stainless-steel sheath and a uranium-dioxide fuel composite was chosen for further development (Samoylov et al. 1976). Fuel elements in the initial modification had a tubular design formed by two coaxial stainless-steel sheaths $(9.4 \times 0.6 \mathrm{~mm}$ and $20 \times 0.3 \mathrm{~mm}$, respectively). Thus, SHS channels with such fuel elements did not differ significantly from BW channels (Figure 7), consisting of 6 fuel elements arranged in a graphite collar with a central steam feeding tube. Steam entered the central tube and was superheated while passing along the fuel bundles.

Later, a U-shape design was developed. The central tube $(9.4 \times 0.6 \mathrm{~mm})$ was replaced with an absorbing soft-control rod $(12 \times 0.6 \mathrm{~mm})$. The decreased width of the active material decreased non-productive neutron absorption and allowed some power flattening. The steam was reheated first passing downward along three fuel bundles and then passing upwards along another three fuel bundles. Such construction reduced temperature conditions for SHS channels and allowed usage of simpler and cheaper materials. Also, reactor-graphite-stack temperature was lowered by $100^{\circ} \mathrm{C}$ at a channel power of $0.36 \mathrm{MW}$. This was achieved with the transfer of heat released in the graphite stack to the downward flow fuel elements that operated at intermediate temperatures (Dollezhal et al. 1964).

Efforts for further improvement of heat and physical parameters were made. They led to another modification of channels and fuel elements. One upward flowing fuel element was eliminated, inner fuel-element sheath was increased to the size of $16 \times 0.7 \mathrm{~mm}$, and outersheath size was increased to $23 \times 0.3 \mathrm{~mm}$.

Physical and thermal parameters improved sharply after such a modification due to decreased matrix material in the fuel elements and increased flow cross-section. 6-elements channels were gradually replaced by 5-elements channels during refuelling of the operating reactor. The reduction of one of the elements increases the steam velocity in the upward flowing fuel elements (Samoylov et al. 1976). Stainless steel was used as the outer-sheath material. Uranium-dioxide dispersed in matrix alloy was used as fuel elements in SHS channels. Improvements in the performance of various BNPP parameters are listed in Table 5. 

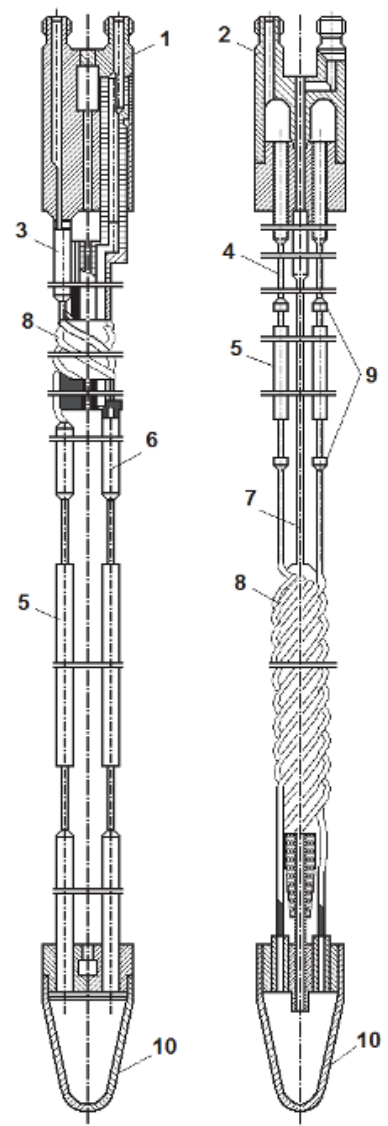

1 - head of boiling-water channel;

2 - head of superheated-steam channel;

3 - three downward-flow strings;

4 - six upward-flow strings;

5 - fuel bundle strings;

6 - three upward-flow strings;

7 - downward-flow strings;

8 - compensators;

9 - welded joints of tubes;

10 - tail.

Fig. 7. Principal design scheme of boiling-water and superheated-steam channels (Emelyanov et al. 1972)

\begin{tabular}{|l|c|c|}
\hline \multicolumn{1}{|c|}{ Parameters } & Before SHSs installation & After SHSs installation \\
\hline Electrical power, $\mathrm{MW}_{\mathrm{el}}$ & $60-70$ & $100-105$ \\
\hline Steam $P_{\text {in }}, \mathrm{MPa}$ & $5.9-6.3$ & $7.8-8.3$ \\
\hline Steam $T_{\text {in }}{ }^{\circ} \mathrm{C}$ & $395-405$ & $490-505$ \\
\hline Exhaust steam $P, \mathrm{kPa}$ & $9-11$ & $3.4-4.0$ \\
\hline $\begin{array}{l}\text { Mass flowrate of water in 1st } \\
\text { loop, } \mathrm{kg} / \mathrm{h}\end{array}$ & 1400 & $2300-2400$ \\
\hline$P$ in separators, $\mathrm{MPa}$ & $9.3-9.8$ & $11.8-12.7$ \\
\hline Gross thermal efficiency, \% & $29-32$ & $35-36$ \\
\hline $\begin{array}{l}\text { Electrical power for internal } \\
\text { needs, } \%\end{array}$ & $10-12$ & $7-9$ \\
\hline
\end{tabular}

Table 5. Average parameters of BNPP Unit 1 before and after installation of superheatedsteam channels (Dollezhal et al. 1969). 


\begin{tabular}{|c|c|c|c|}
\hline \multirow{2}{*}{ Parameters } & \multirow{2}{*}{ BNPP Unit 1} & \multicolumn{2}{|c|}{$\begin{array}{c}\text { BNPP Unit } 2 \\
\text { (U-shaped channel with } 6 \text { fuel elements) }\end{array}$} \\
\hline & & $\begin{array}{l}\text { Downward-flow } \\
\text { fuel elements }\end{array}$ & $\begin{array}{l}\text { Upward-flow fuel } \\
\text { elements }\end{array}$ \\
\hline Max channel power, $\mathrm{kW}$ & 368 & \multicolumn{2}{|c|}{767} \\
\hline Min channel power, kW & 202 & \multicolumn{2}{|c|}{548} \\
\hline $\begin{array}{l}\text { Steam mass-flow rate } \\
\text { through max. power } \\
\text { channel, } \mathrm{kg} / \mathrm{h}\end{array}$ & 1900 & \multicolumn{2}{|c|}{3600} \\
\hline $\begin{array}{l}\text { Steam mass flow rate } \\
\text { through channel } \\
\text { operating at minimal } \\
\text { power, } \mathrm{kg} / \mathrm{h}\end{array}$ & 1040 & \multicolumn{2}{|c|}{2570} \\
\hline Steam $P_{\text {in }} / P_{\text {out }}, \mathrm{MPa}$ & $10.8 / 9.81$ & $12.9 / 12.3$ & $12.2 / 10.8$ \\
\hline Steam $T_{\text {in }} / T_{\text {out }}{ }^{\circ} \mathrm{C}$ & $316 / 510$ & $328 / 399$ & $397 / 508$ \\
\hline Max heat flux, MW $/ \mathrm{m}^{2}$ & 0.56 & 0.95 & 0.79 \\
\hline Max steam velocity, $\mathrm{m} / \mathrm{s}$ & 57 & 76 & 112 \\
\hline $\begin{array}{l}\text { Max } T,{ }^{\circ} \mathrm{C}: \\
\text { sheath } \\
\text { fuel } \\
\text { graphite }\end{array}$ & $\begin{array}{l}530 \\
550 \\
725\end{array}$ & $\begin{array}{l}426 \\
482 \\
735\end{array}$ & $\begin{array}{l}531 \\
565 \\
735\end{array}$ \\
\hline
\end{tabular}

Table 6. Design parameters and operating conditions of superheated-steam channels (Dollezhal et al. 1964).

\subsection{Hydrodynamic stability of the Beloyarsk NPP channels during reactors start-up}

During start-up and nominal operating conditions it is necessary to provide reliable cooling of fuel bundles (crisis-free heat transfer and hydrodynamic stability). Experiments on set-up simulating Units 1 and 2 were performed for determining safe operating conditions for coolant flow rate with no pulsations during the start-up.

Both SHS and BW channels of the BNPP were filled with water in the initial state. During reactor start-up, the water in the SHS channels was to be discharged and transfer to cooling by steam was to be performed. Additionally, the units were preheated and started without external heat sources.

The coolant flow rate stability in the BW channels was studied for wide ranges of pressures, flow rates and powers (Smolin et al. 1965). Special attention was paid to determination of the pressure, flow rate, steam content and power. Different combinations of these parameters created conditions leading to pulsations. When occurred, flow rate pulsations took place when coolant reached saturation temperature at the outlet of the BWs. Pulsations were in the form of coolant flow rate periodical oscillations in peripheral tubes. Oscillations were phase-shifted in different tubes while the total flow rate was constant.

Two pulsation regions were determined as the result of the experiments: small steam content region ( $x=0-15 \%, 3-6$ oscillations per min) and high steam content region $(x=25$ $-80 \%, 15-20$ oscillations per min). Flow rate pulsations in tubes were accompanied by wall 
tube temperature oscillations along its length with the frequency being equal to that of flow rate oscillations. Wall temperature oscillations in the top cross-sections of the heating zone within the small steam content region occurred with a shift to the smaller values in the surface or volumetric boiling zones and to both the smaller and higher values in the economizer zone. Wall temperature oscillations in the top cross-sections of the heating zone within the high steam content shifted only to the higher values causing boiling crisis (Smolin et al. 1965).

The curves distinguishing stability zones (above the curves) from pulsation zones (below the curves) for the BW and SHS channels of the BNPP Unit 2 are shown in Figure 8.

As seen in Figure 8 the range of stable operation of channels broadens with the increase in pressure or increase in flow rate. The stable operation range contracts with the increase in power. The operating conditions that provide stable flow rate and reliable cooling of the BW and SHS channels at the start-up and nominal operating conditions were chosen based on the performed research. The method of replacing water coolant by steam coolant in SHS channels using accumulated heat was accepted for experimental testing of start-up conditions on Unit 1. The method of gradual replacement of water in the SHS channels first by a water-steam mixture and then by steam was accepted for experimental tests of start-up regime on Unit 2 (Smolin et al. 1965). The experimentally obtained data are presented in Figures $9-10$.

Both methods were elaborately tested and proved to provide reliable cooling of the BW and SHS channels during the start-up. They were adapted for the development of the BNPP start-up conditions.

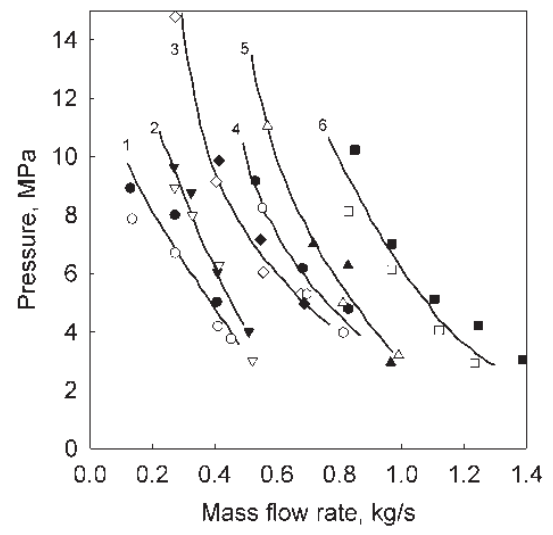

(a)

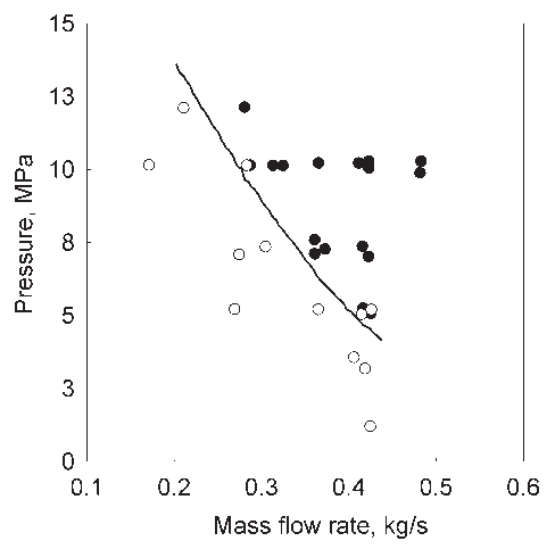

(b)

Fig. 8. Ranges of hydrodynamic stability in BW (a) and SHS (b) channels of BNPP Unit 2 at different channel power (regions of channels stable operation are above curves, closed symbols) (Smolin et al. 1965): 1 - $50 \mathrm{~kW} ; 2$ - $100 \mathrm{~kW} ; 3$ - $200 \mathrm{~kW} ; 4-300 \mathrm{~kW} ; 5-400 \mathrm{~kW}$; and $6-800 \mathrm{~kW}$. 


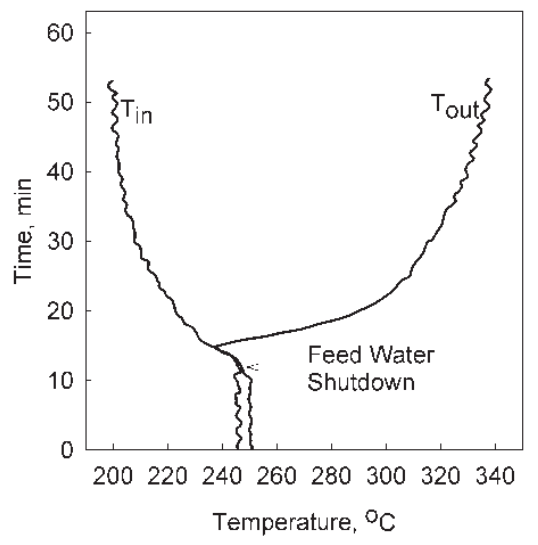

(a)

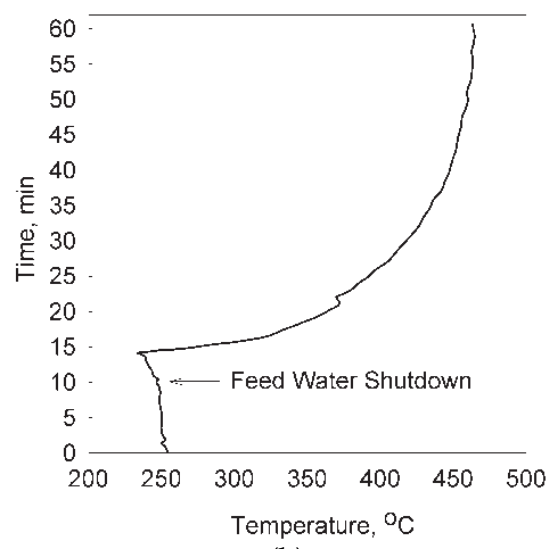

(b)

Fig. 9. Temperature variations at BNPP Unit 1 SHS channels at transitional regime (Smolin et al. 1965): (a) - coolant inlet $\left(T_{\text {in }}\right)$ and outlet temperatures $\left(T_{\text {out }}\right)$ and $(b)$-sheath temperature.

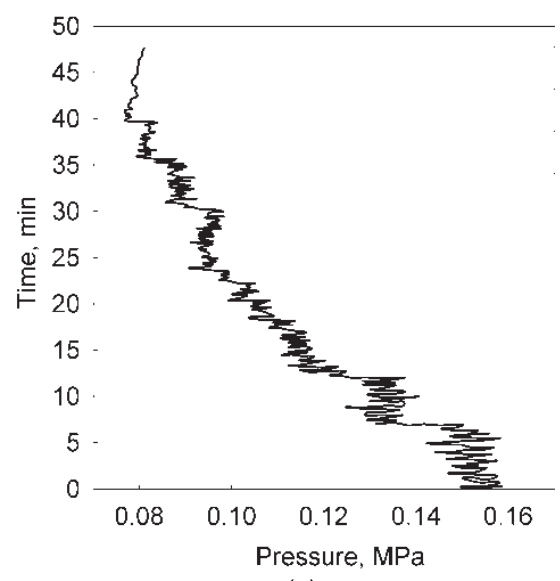

(a)

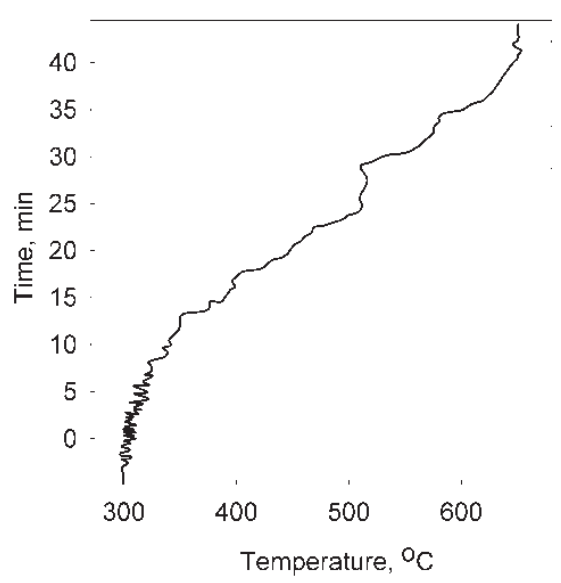

(b)

Fig. 10. Variations of pressure drop (a) and sheath temperature (b) at BNPP Unit 2 during high-power start-up (Smolin et al. 1965).

\subsection{Start-up of Beloyarsk NPP reactors}

The start-up testing of the Unit 1 and Unit 2 reactors of the BNPP are described in this section. During the Unit 1 start-up, both loops were filled with deaerated water, water circulation was established, air was removed, and the pressure was raised up to $10 \mathrm{MPa}$ and $3 \mathrm{MPa}$ in the primary and secondary loops, respectively (Aleshchenkov et al. 1971).

Equipment was heated up at $10-14 \%$ of reactor power. Average heat-up rate was kept at $30^{\circ} \mathrm{C} / \mathrm{h}$ as measured at the separators. This value was chosen based on experience of drum 
boilers operation, though reactor equipment allowed significantly higher heat-up rate. No heat removal was provided during the heat-up to the $160^{\circ} \mathrm{C}$ coolant temperature at the reactor outlet. The water level was formed at $160^{\circ} \mathrm{C}$ in the bubbler and the excess heat started being released to the turbine condenser. When water temperature at the outlet of the SHS channels reached $230^{\circ} \mathrm{C}$ the heat-up was terminated. Total heat-up time was about $9 \mathrm{~h}$. At the next step, water was purged from SHS channels. The transient processes took place in the second loop while constant pressure and boiling-free cooling of BWs were provided in the primary loop. Reactor power was rapidly reduced to $\sim 2 \%$ of its nominal level and feedwater flow rate was reduced to provide water level in the SGs to purge SHS channels. Water-steam mixture from evaporators and steam from the steam loop were directed to the bubbler and then to the deaerator and the turbine condenser.

The purging of SHS channels started after the level in the SGs had been formed. The purging regime was monitored by the pressure drop between the reactor inlet and outlet steam headers and the coolant temperature at the outlet of each SHS channel. Additional steam discharge by increased pressure drop rate was achieved and thus the purging was accelerated by opening gate valves in front of the bubbler for $1-2 \mathrm{~min}$. The pressure drop rate was chosen based upon the allowed temperature condition and was set to $\sim 0.15$ $\mathrm{MPa} / \mathrm{min}$. Overall time for the level formation in the evaporators was $\sim 8-10 \mathrm{~min}$, the time of purging $\sim 6-10 \mathrm{~min}$. The gate valves in front of bubblers were closed and reactor power was increased after the purging had finished. Thus, the pressure and the temperature in SHS channels were increase. After 2 hours the SHS channels purging had been finished and the reactor achieved a stable operation at $10 \%$ power level. The heating of steam pipes and the turbine was initiated and the turbine connection to the power line was prepared. Further power increase was made once the turbine had been connected to the power line.

The first loop was transferred to the boiling flow regime and the separators levels were formed at $35 \%$ reactor power and $\sim 6 \mathrm{MPa}$ pressure. During the transient to the boiling regime, the operating conditions of the MCPs were continuously monitored. Water temperature was maintained $5-6^{\circ} \mathrm{C}$ below the boiling margin for intake pipes of the main circulation pumps. Level formation in the separators was accompanied by smooth pressure change. It took about $3 \mathrm{~h}$ for the water to reach controlled level in the separators, the time being dependent only on the separator bleed lines throughput.

The specific features of a single-circuit flow diagram made the sequence of the BNPP Unit 2 start-up operations somewhat different. SHS channels purging and transition to boiling regime in the BW channels took place simultaneously. Filling of the circuits and equipment heat-up were the same as in Unit 1 . The terminal heat-up parameters were higher $(P \approx 9.3$ $\mathrm{MPa}$ and $\mathrm{T} \approx 290^{\circ} \mathrm{C}$ ). Two main circulation pumps were used to drive coolant circulation in the evaporating loop. After heat-up the reactor power was reduced to $2-3 \%$ of nominal level. SHS channels purging, and transition to boiling regime in the BW channels took place after the heat-up. The feedwater flow rate was considerably reduced, water was purged out of the separators, and the flow rate to the bubblers was increased to form levels in the separators. As a result, the water in the fuel channels and separators boiled causing the purging of water and water-steam mixture from SHS channels. The monitoring of the purging process was the same as at the Unit 1. After SHS channels purging had been completed, the reactor power was increased and steam flow into the bubbler was reduced at the reheated steam temperature rise rate of about $1^{\circ} \mathrm{C} / \mathrm{min}$ with the pressure drop between the steam headers at least $\sim 50-60 \mathrm{kPa}$. The automatic level control system was put into operation as soon as the water in the separators reached the rated level. The subsequent 
reactor power increase, turbine preparation, and connection of the turbine to the power line were the same as for Unit 1 (Aleshchenkov et al. 1971).

\subsection{Pumps}

All pumps at the BNPP were high-speed type $(3000 \mathrm{rpm})$. Serial high-power feeding pumps were used. Other pumps were special canned type, in which the motor spindle and pump spindle were revolved in a pumped medium and were separated from the motor stator by a thin hermetic nichrome plate. Bearing pairs of the pumps were lubricated and cooled by pumped water. The revolving details of bearings were made of advanced hard alloys and bearing bushes were made of special plastics. Some minor failures were observed in operation of MCP (Emelyanov et al. 1972). Those were due to cracks in nichrome jacket, to malfunctioning of fan of the stator front parts, to pilot-valve distribution system imperfections, and to failures of the fasteners in the pump interior. Modernizations of some individual elements of the MCP and reconstruction of independent pump cooling loops improved optimal on-stream time between maintenance and repairing (16,000 h). As a result, the failure probability of the $\mathrm{MCP}$ was reduced to minimum. Operating experience of the MCP showed that serial pumps could be used instead of specially designed canned pumps under no fragment activity in the loops conditions that were achieved at BNPP.

\subsection{Water chemistry}

The experiments on effectiveness of water and steam radiolysis suppression by hydrogen in BW and SHS channels respectively were performed after 16 months of Unit 1 operation. Water and steam samples were taken at the drum-separator, MCPs, inlet and outlet of SHS channels. Ammonia dosing was terminated before the test for determination of the required amount of hydrogen that was necessary to suppress water and steam radiolysis that was partially caused by ammonia decomposition (Yurmanov et al. 2009b). Hydrogen concentration in saturated steam at the separator was found to be $45-88 \mathrm{nml} / \mathrm{kg}$ and in circulation water at the main circulation pump was found to be $2.75-12.8 \mathrm{nml} / \mathrm{kg}$. Despite some hydrogen excess, oxygen concentration decreased from $2.28 \mathrm{mg} / \mathrm{dm}^{3}$ to $0.1 \mathrm{mg} / \mathrm{dm}^{3}$. Dissolved oxygen concentration in the circulating water at the main circulation pump did not exceed $0.01-0.03 \mathrm{mg} / \mathrm{dm}^{3}$. At the next stage of experiments, steam radiolysis in SHS channels and the possibility of suppressing it by hydrogen concentration levels were studied. Hydrogen concentration was set to $1.2-6.2 \mathrm{nml} / \mathrm{kg}$ in steam and $1.2-1.8 \mathrm{nml} / \mathrm{kg}$ in circulating water. Oxygen concentration was below $0.15 \mathrm{mg} / \mathrm{kg}$ in steam and about 0.02 $\mathrm{mg} / \mathrm{dm}^{3}$ in the circulating water. The obtained results demonstrated effective suppression of water radiolysis.

Additional research was carried out at $60 \%$ reactor power. The results showed that the oxygen concentration was decreased to $0.03 \mathrm{mg} / \mathrm{kg}$ at the SHS channels outlet only at 45 $\mathrm{nml} / \mathrm{kg}$ hydrogen concentration. The water-steam mixture at the turbine ejector consisted of hydrogen $(62-65 \%)$ and oxygen $(8-10 \%)$ at a hydrogen concentration of $40-45 \mathrm{nml} / \mathrm{kg}$. The water-steam mixture was needed to be diluted with air to a non-explosive state, i.e., hydrogen volume fraction was to be decreased below 2 - 3\% (Shitzman 1983).

The equipment for Unit 2 was made from the following constructional materials: stainless steel $\left(5500 \mathrm{~m}^{2}, 900 \mathrm{~m}^{2}\right.$ of which were used for the core); carbon steel $\left(5600 \mathrm{~m}^{2}\right)$; brass and cupronickel $\left(14,000 \mathrm{~m}^{2}\right)$; stellite $\left(4.8 \mathrm{~m}^{2}\right)$. The studies showed that radiolytic gases production rate was approximately 5 times lower than that of a BWR of the same power. 
Water radiolysis at the BW channels of the BNPP Unit 1 was suppressed by ammonia dosing. This kept radiolityc oxygen content in water at several hundredths of a milligram per liter. Ammonia dosing wasn't used at Unit 2 due to the danger of corrosion of the condenser tubes and low-pressure heaters. Radiolytic fixation of oxygen in the steam that was bled to high-pressure heaters was achieved by hydrazine hydrate dosing. The operation norms and the actual quality of coolant at the BNPP Unit 2 are listed in the Table 7. Additional information on water flow regime may be found in paper by Konovalova et al. (1971).

All the indicators of coolant quality were in the range set by the water regime regulations during normal operating period.

\begin{tabular}{|l|c|c|c|c|c|}
\hline \multicolumn{1}{|c|}{ Parameters } & $\begin{array}{c}\text { Feed } \\
\text { water }\end{array}$ & $\begin{array}{c}\text { Reactor } \\
\text { circulating } \\
\text { water }\end{array}$ & $\begin{array}{c}\text { Reactor } \\
\text { bleed } \\
\text { water }\end{array}$ & $\begin{array}{c}\text { Saturated / Reheated } \\
\text { steam }\end{array}$ & $\begin{array}{c}\text { Turbine } \\
\text { condensate }\end{array}$ \\
\hline $\mathrm{SiO}^{2-}{ }_{3}, \mu \mathrm{g} / \mathrm{kg}$ & - & - & $100-300$ & $5-15 / 5-15$ & - \\
\hline $\mathrm{Chlorides}, \mu \mathrm{g} / \mathrm{kg}$ & 25 & 25 & 25 & $-/-$ & - \\
\hline Iron oxides, $\mu \mathrm{g} / \mathrm{kg}$ & $20-60$ & $20-60$ & $30-60$ & $20-30 / 20-30$ & 0 \\
\hline Copper, $\mu \mathrm{g} / \mathrm{kg}$ & - & - & $7-30$ & $0.4 /-$ & 0.8 \\
\hline Specific activity, Ci/l & - & - & $10-5$ & $-/ 10-7$ & - \\
\hline Oxygen, $\mu \mathrm{g} / \mathrm{kg}$ & $10-15$ & 30 & 30 & $(5-6) \cdot 10^{3} /(5-6) \cdot 10^{3}$ & $40-50$ \\
\hline Ammonia, $\mathrm{mg} / \mathrm{kg}$ & $1-25$ & $0.6-1.4$ & $0.6-1.4$ & $0.8-2 / 0.8-2$ & $1-2$ \\
\hline $\mathrm{pH}$ & $9.2-9.5$ & $8-9$ & $9-9.5$ & $9-9.5 / 9-9.5$ & $9-9.5$ \\
\hline
\end{tabular}

Table 7. Actual parameters of BNPP Unit 2 coolant quality during period of normal operation (Konovalova et al. 1971).

In August 1972 (after 4.5 years of operation) neutral no-correction water was implemented at Unit 2 (Dollezhal et al. 1974). Operation in the new conditions revealed the following advantages over the ammonia treated state:

1. The cease of feedwater ammonia treatment led to the zero nitrate content in the reactor circulation water. This allowed an increase of the $\mathrm{pH}$ from 4.8 to the neutral level at the $300^{\circ} \mathrm{C}$ operating temperature.

2. Balance of the corrosion products content in the circulation water and chemical flushing of the BW channels showed that the rate of metallic oxide deposits formation on the fuel-bundles surfaces in the evaporating zone of the reactor was three times lower using no-correction water.

3. The Co-60 deposition rate outside the core was 7 - 10 times lower using no-correction water.

4. Condensate purification experience using no-correction water allowed an increasing filter service cycle by 6 times.

\subsection{Section-unit reactor with steam-reheat}

The BNPP became the first in the world industrial NPP with a uranium-graphite power reactor. Examination of the main characteristics of the BNPP reactors (for example, see Table 3) shows that that performance of such type of reactors could be improved. BNPP used slightly enriched uranium and the calculations showed that increasing enrichment to $5 \%$ would increase fuel burn-up $4-10$ times (up to 40,000 MW·days/t). 
All channel reactors were constructed with traditional cylindrical shape of core. Therefore, power increase in such a reactor could be attained by increasing the number of working channels in the core and a proportional increase in diameter size. However, increase in power per reactor would then be limited by the maximum size of the reactor upper plate that could be built and withstand a high load. A way out of this situation was found in section-unit design of the channel reactor with a rectangular core. Such a shape would allow separating not only the core, but also reactor as a whole, into equal geometry sections. Then the reactor of a specified capacity can be constructed of the required number of sections. Each section would stay the same for reactors of different power outputs, and, consequently, core width and maximum size of the upper metalwork would stay the same too. Therefore, the power of a section-unit reactor power would not be limited by the size of the upper plate (Emelyanov et al. 1982).

Section-unit type reactors with coolant at supercritical fluid conditions (see Figure 11) was developed at Research and Development Institute of Power Engineering (RDIPE, Moscow, Russia) as an improvement to the existing RBMK (Russian acronym for Channel Reactor of High-Power).

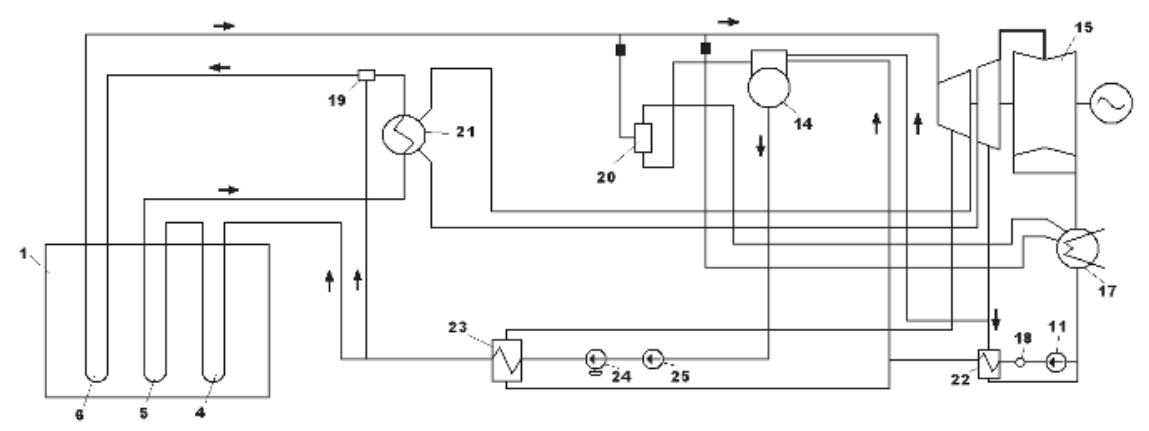

Fig. 11. Schematic of RDIPE SCW NPP (Aleshchenkov et al. 1971): 1 - reactor; 4 - preheating channel; 5 - first SHS; 6 - second SHS; 11 - Condensate Extraction Pump (CEP); 14 deaerator; 15 - turbo-generator; 17 - condenser; 18 - condenser purifier; 19 - mixer; 20 start-up separator; 21 - intermediate steam reheater; 22 - low-pressure regenerative preheater; 23 - high-pressure regenerative preheater; 24 - feed turbo-pump; and 25 booster pump.

Rod fuel bundles were inserted into Zirconium SHS (SHS-Z) channels (see Figure 12) on the core level. $\mathrm{UO}_{2}$ fuel elements with steel sheath were designed. Fuel bundles were covered by a sheath to hold SHS-Z channel wall below $360^{\circ} \mathrm{C}$ (Grigoryants et al. 1979). Therefore, saturated steam entering the channel was split into two streams. About $25 \%$ of the steam flowed through the annular gap cooling the SHS-Z channel wall. Both streams mixed at the core exit. Steam mixture was at about $455^{\circ} \mathrm{C}$. Tests with SHS-Z channels were performed in BNPP Unit 1 to check design decisions. SHS-Z channels were tested in 23 - 24 start-ups shutdowns, including 11 emergency shutdowns of the reactor when the steam temperature change rate was $20-40^{\circ} \mathrm{C} / \mathrm{min}$ during the first 3 minutes of an automatic control system operation, and $5^{\circ} \mathrm{C} / \mathrm{min}$ after that. SHS-Z channel wall temperature reached $400-700^{\circ} \mathrm{C}$ and that of the fuel bundles sheath reached $650-740^{\circ} \mathrm{C}$ during start-up operation at a steam 
pressure of $2.45-4.9 \mathrm{MPa}$. Channels were operated about $140 \mathrm{~h}$ at high temperature conditions. Studies showed that fuel element seal failures were mainly due to short-duration overheating (Mikhan et al. 1988).

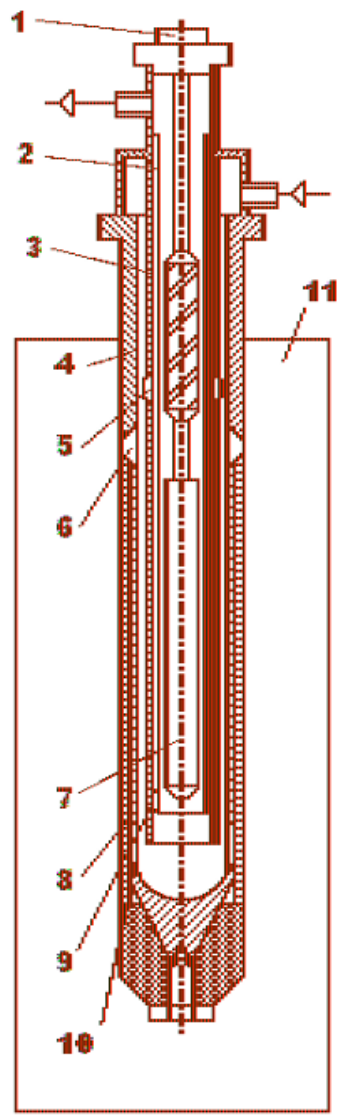

1 - suspension rod;

2 - thermal screen;

3,4 - outer and inner tubes of bearing body;

5 - inner tube reducer;

6 - upper reducer of outer tube;

7 - fuel bundle;

8 - graphite sleeves;

9 - thermal screen and inner tube seal;

10 - lower reducer of outer tube; and

11 - reactor.

Fig. 12. Principal scheme of SHS-Z (Mikhan et al. 1988)

Additional information on SHS-Z-channel tests in BNPP Unit 1 may be found in the papers by Grigoryants et al. (1979) and by Mikhan et al. (1988).

\section{Conclusions}

The operating experience of the reactors with nuclear steam reheat worldwide provides vital information on physical and engineering challenges associated with implementation of steam reheat in conceptual SuperCritical Water-cooled Reactors (SCWRs). Major advancements in implementation of steam reheat inside the reactor core were made in the USA and Russia in 1960s - 1970s. Three experimental reactors were designed and tested in the 1960s - 1970s in the USA. In the former Soviet Union, nuclear steam reheat was implemented at two units at the Beloyarsk NPP. Operating experience of the units showed a 
possibility of reliable and safe industrial application of nuclear steam reheat right up to outlet temperatures of $510-540^{\circ} \mathrm{C}$ after over a decade of operation. Thermal efficiency of the Beloyarsk NPP units was increased by $5 \%$ as the result of implementing nuclear steam reheat. The introduction of nuclear steam reheat was economically justified in cases where the steam was superheated up to $500^{\circ} \mathrm{C}$ and higher with the use of stainless-steel-sheath fuel elements.

The experiments and operating experience obtained to date also indicate that further improvements in SHS channel design and in reactor design are possible.

\section{Acknowledgements}

Financial supports from the NSERC/NRCan/AECL Generation IV Energy Technologies Program and NSERC Discovery Grant are gratefully acknowledged.

The authors would like to acknowledge contributions of Wargha Peiman, Amjad Farah and Krysten King.

\section{Nomenclature}

$K_{\text {eff }} \quad$ effective multiplication constant

$K_{i r} \quad$ neutron flux irregularity coefficient

$P \quad$ pressure, $\mathrm{MPa}$

$R \quad$ radius, $\mathrm{m}$

T temperature, ${ }^{\circ} \mathrm{C}$

$\mathrm{x} \quad$ steam quality

\section{Greek letters}

$\pi \quad$ power split between superheated-steam and boiling-water and channels

\section{Subscripts}

$\begin{array}{ll}\text { el } & \text { electrical } \\ \text { in } & \text { inlet } \\ \text { out } & \text { outlet } \\ \text { th } & \text { thermal }\end{array}$

\section{Abbreviations and Acronyms}

$\begin{array}{ll}\text { AECL } & \text { Atomic Energy of Canada Limited } \\ \text { BNPP } & \text { Beloyarsk Nuclear Power Plant } \\ \text { BONUS } & \text { BOiling NUclear Superheater } \\ \text { BORAX } & \text { BOiling Reactor Experiment } \\ \text { BW } & \text { Boling-Water (channel) } \\ \text { BWR } & \text { Boiling Water Reactor } \\ \text { CEP } & \text { Condenser-Extraction Pump } \\ \text { ESADE } & \text { Superheat Advance Demonstration Experiment } \\ \text { FWP } & \text { FeedWater Pump } \\ \text { MCP } & \text { Main Circulation Pump } \\ \text { NSERC } & \text { Natural Sciences and Engineering Research Council (Canada) } \\ \text { NPP } & \text { Nuclear Power Plant }\end{array}$


NRCan Natural Resources of Canada

RBMK Russian Acronym for Channel Reactor of High-Power

RDIPE Research and Development Institute of Power Engineering (Moscow, Russia)

SADE Superheat Advance Demonstration Experiment

SCW Supercritical Water

SCWR SuperCritical Water-cooled Reactor

SG Steam Generator

SHS SuperHeated Steam (channel)

SS Stainless Steel

USAEC United States Atomic Energy Commission

Z Zirconium

\section{References}

Aleshchenkov, P.I., Zvereva, G.A., Kireev, G.A., Knyazeva, G.D., Kononov, V.I., Lunina, L.I., Mityaev, Yu.I., Nevskii, V.P., and Polyakov, V.K., 1971. Start-up and Operation of Channel-Type Uranium-Graphite Reactor with Tubular Fuel Elements and Nuclear Steam Reheating, Atomic Energy (Атомная Энергия, стр. 137-144), 30 (2), pp. $163-$ 170.

Aleshchenkov, P.I., Mityaev, Yu.I., Knyazeva, G.D., Lunina, L.I., Zhirnov, A.D., and Shuvalov, V.M., 1964. The Kurchatov's Beloyarsk Nuclear Power Plant, (In Russian) Atomic Energy, 16 (6), pp. 489-496.

Dollezhal, N.A., Malyshev, V.M., Shirokov, S.V., Emel'yanov, I.Ya., Saraev, Yu.P., Aleshchenkov, P.I., Mityaev, Yu.I., and Snitko, E.I., 1974. Some Results of Operation of the I.V. Kurchatov Nuclear Power Station at Belyi Yar, Atomic Energy (Атомная Энергия, стр. 432-438), 36 (6), pp. 556-564.

Dollezhal, N.A., Aleshchenkov, P.I., Bulankov, Yu.V., and Knyazeva, G.D., 1971. Construction of Uranium-Graphite Channel-Type Reactors with Tubular Fuel Elements and Nuclear-Reheated Steam, Atomic Energy (Атомная Энергия, стр. 149-155), 30 (2), pp. 177-182.

Dollezhal, I.Ya., Aleshchenkov, P.I., Evdokimov, Yu.V., Emel'yanov, I.Ya., Ivanov, B.G., Kochetkov, L.A., Minashin, M.E., Mityaev, Yu.I., Nevskiy, V.P., Shasharin, G.A., Sharapov, V.N., and Orlov, K.K., 1969. BNPP Operating Experience, (In Russian), Atomic Energy, 27 (5), pp. 379-386.

Dollezhal, N.A., Emel'yanov, I.Ya., Aleshchenkov, P.I., Zhirnov, A.D., Zvereva, G.A., Morgunov, N.G., Mityaev, Yu.I., Knyazeva, G.D., Kryukov, K.A., Smolin, V.N., Lunina, L.I., Kononov, V.I., and Petrov, V.A., 1964. Development of Power Reactors of BNPP-Type with Nuclear Steam Reheat, (In Russian), Atomic Energy, (11), pp. 335-344 (Report No. 309, 3rd International Conference on Peaceful Uses of Nuclear Energy, Geneva, 1964).

Dollezhal, N.A., Krasin, A.K., Aleshchenkov, P.I., Galanin, A.N., Grigoryants, A.N., Emel'anov, I.Ya., Kugushev, N.M., Minashin, M.E., Mityaev, Yu.I., Florinsky, B.V., and Sharapov, B.N., 1958. Uranium-Graphite Reactor with Reheated High Pressure Steam, Proceedings of the $2^{\text {nd }}$ International Conference on the Peaceful Uses of Atomic Energy, United Nations, Vol. 8, Session G-7, P/2139, pp. 398-414. 
Emelyanov, I.Ya. , Mikhan, V.I., Solonin, V.I., Demeshev, R.S., Rekshnya, N.F., 1982. Nuclear Reactor Design, (In Russian). Energoizdat Publishing House, Moscow, Russia, 400 pages.

Emelyanov, I.Ya., Shasharin, G.A., Kyreev, G.A., Klemin, A.I., Polyakov, E.F., Strigulin, M.M., Shiverskiy, E.A., 1972. Assessment of the Pumps Reliability of the Beloyarsk NPP from Operation Data, (In Russian). Atomic Energy, 33 (3), pp. 729-733.

Grigoryants, A.N., Baturov, B.B., Malyshev, V.M., Shirokov, S.V., and Mikhan, V.I., 1979. Tests on Zirconium SRCh in the First Unit at the Kurchatov Beloyarsk Nuclear Power Station, Atomic Energy (Атомная Энергия, стр. 55-56), 46 (1), pp. 58-60.

Konovalova, O.T., Kosheleva, T.I., Gerasimov, V.V., Zhuravlev, L.S., and Shchapov, G.A., 1971. Water-Chemical Mode at the NPP with Channel Reactor and Nuclear Steam Reheat, (In Russian), Atomic Energy, 30 (2), pp. 155-158.

Mikhan, V.I., Glazkov, O.M., Zvereva, G.A., Mihaylov, V.I., Stobetskaya, G.N., Mityaev, Yu.I., Yarmolenko, O.A., Kozhevnikov, Yu.N., Evdokimov, Yu.V., Sheynkman, A.G., Zakharov, V.G., Postnikov, V.N., Gladkov, N.G., and Saraev, O.M., 1988. Reactor Testing of Zirconium Steam-Reheat Channels with Rod Fuel Elements in Reactors of the First Stage of BNPP, (In Russian), BNPP Operating Experience: Information Materials (in 4 volumes), USSR Academy of Sciences, Ural Branch, 207 pages.

Novick, M., Rice, R.E., Graham, C.B., Imhoff, D.H., and West, J.M., 1965. Developments in Nuclear Reheat, Proceedings of the 3rd International Conference, Geneva, Vol. 6, pp. 225-233.

Petrosyants, A.M., 1969. Power Reactors for Nuclear Power Plants (from the First in the World to the 2-GW Electrical Power NPP) , (In Russian). Atomic Energy, 27 (4), pp. 263-274.

Pioro, I., Saltanov, Eu., Naidin, M., King, K., Farah, A., Peiman, W., Mokry, S., Grande, L., Thind, H., Samuel, J. and Harvel, G., 2010. Steam-Reheat Option in SCWRs and Experimental BWRs, Report for NSERC/NRCan/AECL Generation IV Energy Technologies Program (NNAPJ) entitled “Alternative Fuel-Channel Design for SCWR" with Atomic Energy of Canada Ltd., Version 1, UOIT, Oshawa, ON, Canada, March, 128 pages.

Ross, W.B., 1961. Pathfinder Atomic Power Plant, Superheater Temperature Evaluation Routine, An IBM-704 Computer Program. United States Atomic Energy Commission, Office of Technical Information, Oak Ridge, TN, 49 pages.

Samoilov, A.G., Pozdnyakova, A.V., and Volkov, V.S., 1976. Steam-Reheating Fuel Elements of the Reactors in the I.V. Kurchatov Beloyarsk Nuclear Power Station, Atomic Energy (Атомная Энергия, стр. 371-377), 40 (5), pp. 451-457.

Shitzman, M.E., 1983. Neutral-Oxygen Water Regime at Supercritical-Pressure Power Units, (in Russian), Energoatomizdat Publishing House, Moscow, Russia.

Smolin, V.N., Polyakov, V.K., Esikov, V.I., and Shuyinov, Yu.N., 1965. Test Stand Study of the Start-up Modes of the Kurchatov's Beloyarsk Nuclear Power Plant, (In Russian). Atomic Energy, 19 (3), pp. 261-269.

USAEC Report ACNP-5910, 1959. Allis-Chalmers Manufacturing Co., Pathfinder Atomic Power Plant, Final Safeguards Report, May.

USAEC Report (MaANL-6302), 1961. Design and Hazards Summary Report-Boiling Reactor Experiment V (Borax-V), Argonne National Laboratory. 
USAEC Report PRWRA-GNEC 5, 1962. General Nuclear Engineering Corp., BONUS, Final Hazards Summary Report, February.

Vikulov, V.K., Mityaev, Yu.I., Shuvalov, V.M. , 1971. Some Issues on Beloyarsk NPP Reactor Physics, (In Russian), Atomic Energy, 30 (2), pp. 132-137.

Yurmanov, V.A., Belous, V. N., Vasina, V. N., and Yurmanov, E.V., 2009a. Chemistry and Corrosion Issues in Supercritical Water Reactors, Proceedings of the IAEA International Conference on Opportunities and Challenges for Water Cooled Reactors in the 21 $1^{\text {st }}$ Century, Vienna, Austria, October 26-30.

Yurmanov, V.A., Vasina, V. N., Yurmanov, E.V and Belous, V. N., 2009b. Water Regime Features and Corrosion Protection Issues in NPP with Reactors at Supercritical Parameters", (In Russian), Proceedings of the IAEA International Conference on Opportunities and Challenges for Water Cooled Reactors in the $21^{\text {st }}$ Century, Vienna, Austria, October 26-30. 


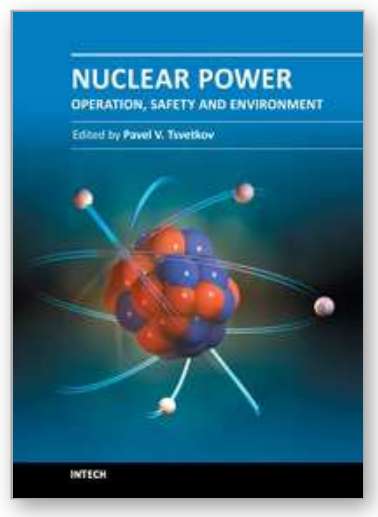

\author{
Nuclear Power - Operation, Safety and Environment \\ Edited by Dr. Pavel Tsvetkov
}

ISBN 978-953-307-507-5

Hard cover, 368 pages

Publisher InTech

Published online 06, September, 2011

Published in print edition September, 2011

Todayâ $€^{\mathrm{TM}} \mathrm{S}$ nuclear reactors are safe and highly efficient energy systems that offer electricity and a multitude of co-generation energy products ranging from potable water to heat for industrial applications. At the same time, catastrophic earthquake and tsunami events in Japan resulted in the nuclear accident that forced us to rethink our approach to nuclear safety, design requirements and facilitated growing interests in advanced nuclear energy systems, next generation nuclear reactors, which are inherently capable to withstand natural disasters and avoid catastrophic consequences without any environmental impact. This book is one in a series of books on nuclear power published by InTech. Under the single-volume cover, we put together such topics as operation, safety, environment and radiation effects. The book is not offering a comprehensive coverage of the material in each area. Instead, selected themes are highlighted by authors of individual chapters representing contemporary interests worldwide. With all diversity of topics in 16 chapters, the integrated system analysis approach of nuclear power operation, safety and environment is the common thread. The goal of the book is to bring nuclear power to our readers as one of the promising energy sources that has a unique potential to meet energy demands with minimized environmental impact, near-zero carbon footprint, and competitive economics via robust potential applications. The book targets everyone as its potential readership groups - students, researchers and practitioners - who are interested to learn about nuclear power.

\title{
How to reference
}

In order to correctly reference this scholarly work, feel free to copy and paste the following:

Eugene Saltanov and Igor Pioro (2011). World Experience in Nuclear Steam Reheat, Nuclear Power Operation, Safety and Environment, Dr. Pavel Tsvetkov (Ed.), ISBN: 978-953-307-507-5, InTech, Available from: http://www.intechopen.com/books/nuclear-power-operation-safety-and-environment/world-experience-innuclear-steam-reheat

\section{INTECH}

open science | open minds

\section{InTech Europe}

University Campus STeP Ri

Slavka Krautzeka 83/A

51000 Rijeka, Croatia

Phone: +385 (51) 770447

Fax: +385 (51) 686166

\section{InTech China}

Unit 405, Office Block, Hotel Equatorial Shanghai

No.65, Yan An Road (West), Shanghai, 200040, China 中国上海市延安西路65号上海国际贵都大饭店办公楼 405 单元

Phone: +86-21-62489820

Fax: +86-21-62489821 
www.intechopen.com 
(C) 2011 The Author(s). Licensee IntechOpen. This chapter is distributed under the terms of the Creative Commons Attribution-NonCommercialShareAlike-3.0 License, which permits use, distribution and reproduction for non-commercial purposes, provided the original is properly cited and derivative works building on this content are distributed under the same license. 